\title{
Students' Written Production Error Analysis in the EFL Classroom Teaching: A Study of Adult English Learners Errors
}

\author{
Ronauli Sihombing \\ Indonesia University of education \\ ronaulisihombing@student.upi.edu \\ Astri Khoirun Nissa \\ Indonesia University of education \\ astrisirait@student.upi.edu \\ Amelia Estrelita \\ Indonesia University of education \\ amel_rainism@yahoo.com
}

\section{Abstract}

Errors analysis has become one of the most interesting issues in the study of Second Language Acquisition. It can not be denied that some teachers do not know a lot about error analysis and related theories of how L1, L2 or foreign language acquired. In addition, the students often feel upset since they find a gap between themselves and the teachers for the errors the students make and the teachers' understanding about the error correction. The present research aims to investigate what errors adult English learners make in written production of English. The significances of the study is to know what errors students make in writing that the teachers can find solution to the errors the students make for a better English language teaching and learning especially in teaching English for adults. The study employed qualitative method. The research was undertaken at an airline education center in Bandung. The result showed that syntax errors are more frequently found than morphology errors, especially in terms of verb phrase errors. It is recommended that it is important for teacher to know the theory of second language acquisition in order to know how the students learn and produce theirlanguage. In addition, it will be advantages for teachers if they know what errors students frequently make in their learning, so that the teachers can give solution to the students for a better English language learning achievement.

Keywords: Adult learners, errors analysis, EFL classroom teaching, written production.

\section{A. INTRODUCTION}

In the study of Second Language Acquisition, errors analysis has become one of the most interesting issues because in second / foreign language learning, error correction has become one of the important teaching processes. Actually few teachers know a lot about error analysis and related theories and they often take so negative attitudes toward errors that they could not tolerate and tend to correct them as soon as they could find any (Fang \& Xue-mei, 2007). As the result, the students often feel upset since they find gap between themselves and the students for the errors the students make and the teacher's understanding about the error correction.

Studies conducted on the speech and writing of adults second language 
learning found that the majority of errors made by the students are inter-lingual errors (Dulay, Burt \& Krashen, 1982). It means that students still find a gap between their L1 and L2, and Ln rather than errors produced as the reflection of their mother tongue. The study of contrastive analysis has come to a further research for this issues. So, as the alternative of contrastive analysis, the study of error analysis has been conducted.

Research on error analysis have been conducted in different levels and areas. Tulldahl (2004) conducted research on analysis of errors in the written production of Swedish adolescent learners of English and it is found that errors are produced by learners making faulty inferences about the rules of the new language. It occurs when the learners is unmotivated, lacking in confidence, or concerned with failure. Research on error analysis and the EFL classroom teaching (Khansir, 2012 and Fang \& Xue-Mei, 2007) found that the learner of English as a second language is unaware of the existence of the particular system or rule in English language. So, it is suggested that teachers should employ different and flexible error treatment strategies in accordance with the teaching objectives, students' linguistic competence, their affective factors and the effectiveness of the error correction. The study of error analysis on students' with disabilities also have been conducted previously, of which is dyslexia students (Tops, et al., 2012). It is found that higher education students of dyslexia made on average twice and many spelling errors.

It is seldom found that teachers know the theory of second language acquisition, including how the students produce errors, what errors the students make, and how to handle the errors. Therefore, the present research aims to investigate what errors students make in writing production of adult learners by employing these two research question: "What errors students make in writing production?" The significances of the study is know what errors students make in writing and teachers can find solution the errors the students make for a better English language teaching and learning.

Error analysis was established in the 1960s by Stephen Pit Corder and colleagues or over 40 years (Tulhadl, 2004). Error analysis was an alternative to contrastive analysis. Error analysis showed that contrastive analysis was unable to predict a great majority of errors, although it is more valuable aspects have been incorporated in to the study of language transfer. As Lado in (Gass \& Selinker, 2008) states that one way of fulfilling the injunction to check hypothetical problems against actual learner production was to refocus on learner errors from which developed an approach called error analysis.

Error analysis is a type of linguistic analysis that focuses on the errors learners make that is not viewed solely as a product of imperfect learning; hence, they are not something for teachers to throw their hands up in the air about (Gass \& Selinker, 2008). Gass and Selinker (2008) adds that,

"focus on errors is the beginning of the field of Second Language Acquisition, which at this point is the beginning to emerge as a field of interest not only for the pedagogical implications that may result from knowing about second language learning, but also because of the theoretical implication for fields such as psychology (in 
particular learning theory) and linguistics" (pp. 102).

Therefore, it can be concluded that study on error analysis is one of interesting topics in Second Language Acquisition study.

Dulay, Burt and Krashen (1982) suggest that errors are flawed side of learner speech or writing and they are parts of conversation or composition that deviate from some selected norm of mature language performance. There are two purposes of studying learners' errors proposed by Dulay, Burt and Krashen (1982), they are: 1) providing data from which inferences about the nature of the language learning process can be made and 2) indicating to teachers and curriculum developers which part of the target language students have most difficulty producing correctly and which error types detract most from a learner's ability to communicate effectively. Researchers have found that like L1 learners' errors, most of the errors L2 learners make indicate they are gradually building an $\mathrm{L} 2$ rule system.

There are some errors made by the students. Politzer and Ramirez in (Dulay, Burt and Krashen, 1982, pp. 138) propose among the most common errors: 1) Omitting grammatical morphemes, which are items that do not contribute much to the meaning of sentences, as He hit car; 2) Double making, a semantic feature (e.g. past tense) when only one marker is required, as in She didn't went back; 3) Regularizing rules, as in women for women; 4) Using archiforms-one form in place of several-such as the use of her for both she and her, as in I see heryesterday. Herdance with my brother; 5) Using two or more forms in random alternation even though the language requires the use of each only under certain conditions, as in the random use of he and she regardless of the gender of the person of interest; 6) Misordering items in construction that require a reversal of word-order rules that had been previously acquired, as in what you are doing?, or misplacing items that may be correctly placed in more than one place in the sentence, as in They are all the time late.

Many error taxonomy have been based on the linguistic item which is affected by an error. These linguistic category taxonomies classify errors according to either or both the language components and the particular linguistic constituent the error affects. Language components include (pronunciation), syntax and morphology (grammar), and discourse (style).

Adult studies conducted on the speech and writing of adults learning English as a second language have reached similar conclusions, namely, that the majority of non-phonological errors observed for adults do not reflects the first language (Dulay, Burt and Krashen, 1982). $8 \%$ to $23 \%$ of the adult errors may classified as interlingual. Interlingual errors are errors which can be attributed to the native language, for example, they involve cross-linguistic comparisons (Gass and Selinker, 2008).

Brown (1993) differentiates between mistakes and errors. A mistake is a performance error that is either a random guess or slip in that it is a failure to utilize a known system correctly. Native speakers are normally capable of recognizing or correcting such mistakes, which are not the result of a deficiency in competence but the result of some sort of breakdown in the process of production. An error is a noticeable deviation, reflecting the competence of the learner. It is a systematic deviation made by the 
learner who has not yet mastered the rule of the target language. The learner can not do a self-correct to an error because it is a product reflective of his or her current stage of L2 development, or underlying competence (Larsen, 1992).

A great deal of the work on error analysis was carried out within the context of the classroom as one of the purpose of pedagogical remediation (Gass and Selinker (2008). There are some steps taken in conducting error analysis (Gass \& Selinker , 2008 and Ellis, 1997).

1) Collect data, the data can be collected in the form of both written and oral data.

2) Identify errors, to identify errors we have to compare the sentences learners produce with what seem to be the normal or correct sentences in the target language which correspond with them.

3) Describes errors, there are several ways in describing errors. One way is to classify errors in to grammatical categories, another way might be to try to identify general ways in which the learners' utterance differ from reconstructed target-language utterances

4) Explain errors, the identification and description of errors are preliminaries to the much more interesting task of trying to explain why they occur.

5) Remediate / Error Evaluation, based on the kind and frequency of an error type, we can carry out pedagogical intervention.

\section{B. RESEARCH METHOD}

This chapter reviews the research methodology. It includes research design, site and participants, research instruments, data collection and data analysis. The study employed qualitative method. In order to gain in-depth understanding of an issue, qualitative research methodology is best suited (Hamied \& Malik, 2014). In addition, by applying qualitative research, the quality of relationships, activities, situations and materials can be emerged (Fraenkel, Wallen \& Wallen, 2012).The research was undertaken at an aviation academy in Bandung by deploying purposive sampling. The participants were 10 adult learners at the academy. The participants were selected based on the level of their English proficiency in the academy, namely at the students at the end of the term. Tthe researcher decided to choose them as participants for the reasons that they have learned for a particular time until the end of the program.

The data were collected by asking the students to retell the story they had watched first in the form of story-telling. The use of preselected story presented to a learner in either written, picture or video have been widely used as technique in narrative language elicitation (Doughty \& Long, 2007). Larsen and LarsenFreeman in Doughty \& Long (2007) also add that non dialogue files have been used to elicit L2 English production. The students were triggered by giving a movie to watch.

The collected data were analyzed based on the research questions by using Miles and Huberman qualitative data analysis. It consists of data reduction that refers to the process of selecting, focusing, simplifying the data in written up transcription. Then the data are displayed in the form of extracted text and finally, the data are concluded and verified (Miles \& Huberman, 1994). Data analysis adapted from Politzer and Ramirez in Dulay, Burt and Krashen (1982) who categorized errors in to two categories, Morphology (indefinite article, possessive case, third person singular, and past participle) and Syntax (noun phrase, verb phrase, verb and verb 
construction, word order, some transformations).

\section{FINDINGS AND DSCUSSION}

The written data were extracted for analysis based on both linguistic category and surface strategy taxonomy adapted from Politzer and Ramirez in Dulay, Burt and Krashen (1982). The results can be seen in the table below.

\section{Table 1. Linguistic Category Taxonomy and Surface Strategy Taxonomy}

\section{Linguistic Category and Error Type}

\section{A. Morphology}

1. Indefinite article incorrect

2. Possessive case incorrect

3. Third person singular verb incorrect

- Failure to attach -s

4. Simple past tense incorrect

a. Regular past tense

- Omission of -ed

b. Irregular past tense

- Substitution of simple non-past

- Regularization of to be

\section{Learners' Error}

-(she) was not invited to celebrate prince and snow white ('s wedding)

- a littel baby who want to ...

-Once upon a time tell (tells) about Evil Queen, Snow white and Prince Charming -she is revenge (revenged) to Snow White - the prince kiss (kissed) the snow white

- this story show (showed) about love
- and have (had) a child named Emma

- Because she think (thought) that....

- Evil Queen come (came) and giving (gave) a curse $(3 \times)$

-And then snow white have (had) a child named Emma

- The movie begin (began) the prince kiss the snow white

- the story always give (gave) a new action in every season

-Atmosphere in the cathedral is (was) very happy before evil queen is (was) coming.

- Evil queen is (was) very angry

5. Past participle incorrect

6. Comparative adjective / adverb incorrect 


\section{B. Syntax}

1. Noun phrase

a. Determiners

- Omission of the article

- Use of wrong possessive

- Use of wrong determiner

b. Nominalization

c. Number

d. Use of pronoun

- Omission of possessive pronoun

e. Use of preposition

2. Verb phrase

a. Omission of verb

- Omission of main verb

- Omission of to be

b. Use of progressive tense

- Omission of to be

c. Agreement of subject and verb

- Disagreement of subject and verb person

- Disagreement of subject and verb number
-Once upon a time is a story (about) Snow White and Prince Charming

- they (their) name is snow white and prince charming

-Once upon a time is the story about a (omit 'a) lovers.

-On the wedding day snow and (her) true love

- and then the story is (get) better

- so that all (be)happy

- The story of once upon a time (was) very interesting to watch

- That story (was) in a castle

- The story (was) very interesting

-It (is) telling about Evil Queen named Regina

- They (their) name is (are) Snow White and Prince Charming

- Them is (they) married

-Once upon a time is the story about (omit 'a') lovers

- Every crime have (has) .... d. Use of the pronouns

- Omission of the subject pronoun -(the story / it) telling about Evil Queen named Regina

- Evil queen is very angry because her (she) was not invited to celebrate prince and 
snow white

- Omission of object pronoun

3. Verb-and-verb construction

- Omission of adjective clause
-Once upon a time tells (us) the story two people named Snow White and Prince Charming
-Once upon a time tells the story of an evil queen named Regina (who) is eager to get revenge

- The movie begin begin (when) the prince kiss the snow white

4. Word order

5. Some transformation
a. Negative transformation
b. Question transformation
c. There transformation
d. Subordinate clause transformation

6. Passive Sentences

1. Problems with formation of passive sentences

- Active order but passive form

- the new born child snow white and prince charming must hide

- a little baby who want to take by evil Queen

- The baby is name (named) Emma Swan.

- Passive order but active form

2. Inappropiate use of passive

The data showed that the students made errors in the terms of morphology and syntax. The errors in morphology include possessive case incorrect, third person singular verb incorrect (including failure to attach - s), simple past tense incorrect both in regular past tense (omission of -ed) and irregular past tense (substitution of simple non-past), and regularization of to be. While the syntax errors including noun phrase in term of the use of determiners (omission of the article, use of wrong possessive, use of wrong determiner, use of pronoun, and omission of possessive pronoun), verb phrase including omission of verb (omission of main verb, Omission of to be), Use of progressive tense (omission of to be), agreement of subject and verb (disagreement of subject and verb person, disagreement of subject and verb number), Use of the pronouns (omission of the subject pronoun and omission of object pronoun), Verb-and-verb construction (omission of adjective clause), passive Sentences (problems with formation of passive sentence; active order but passive form and passive order but active form). 


\section{CONCLUSION AND SUGGESTIONS}

The errors analyzed in the present study were morphology and syntax errors. It is concluded that syntax errors are more frequently found, especially in terms of verb phrase error, like the omission of main verb, omission of to be, subject verb agreement, and subject number agreement. The rest are in the terms of building passive sentences and verb-and-verb construction. The errors in terms of morphology are about the errors in possessive case, the use of regular and irregular past tense, and to be regulation. It is recommended that it is important for teacher to know the theory of second language acquisition to know how the students learn both young and adult learners. In addition, it will be an advantages for teachers if they know what errors students frequently made in their learning, so that the teachers can give solution to the students for a better language learning achievement.

\section{REFERENCES}

Brown, H. D. (1993). Principles of Language Learning and Teaching. San Fransisco: Prentice Hall Regents.

Doudgty, C. \& Long, M. H. (2007).The Handbook of Second Language Acquisition. California: Blackwell.

Dulay, H., Burt, M., \& Krashen, S. (1982). Language Two. New York: Oxford University Press.

Ellis, R. (1997). Second Language Acquisition. New York: Oxford University Press.

Fang, X., \& Xue-mei, J. (2007). Error analysis and the classroom teaching. US-China Review College

of Foreign Languages Liaoning

Normal Universities, 4(9). pp. 1014.

Fraenkel, Wallen \& Hyun, H. H., (2012). How to design and evaluate research in education. New York: Mc Graw Hill.

Gass, M. \& Selinker, R. (2008). Second Language Acquisition: An Introductory Course. New York, NY: Routledge.

Larsen, D., et al. (1992). An Introduction to Second Language Acquisition Research. London: Longman.

Khansir, A., A. (2012). Error analysis and Second Language Acquisition. Academy Publisher, 2(5). pp. 10271032.

Malik, R. S., \& Hamied, F. A., (2014). Research Methods: A guide for first time researchers. Bandung: UPI Press

Tops, W. et al. (2014). Spelling in adolescents with dyslexia: errors and modes of assessment. Journal of Learning Disabilities, 47(4). pp. 295-306.

Tulldahl, K., D. (2004). Study and analysis of errors in the written production of Swedish adolescent learners of English comparing the evolution of a class at two different points in time. Teacher Training Programme. Swedish: Linkoping University. 